\title{
Kienböck's disease: insidious unilateral wrist pain
}

\author{
Donald James Davidson, Raymond E Anakwe
}

Department of Trauma and Orthopaedics, Imperial College Healthcare NHS Trust, London, UK

Correspondence to Donald James Davidson, d.j.davidson.02@cantab.net

Accepted 3 May 2014

\section{DESCRIPTION}

Kienböck's disease (KD) is characterised by avascular necrosis of the lunate bone and is of unknown aetiology. KD is thought to result from a combination of vascular, anatomic and traumatic insults resulting in interruption of the blood supply to the lunate and osteonecrosis. ${ }^{1}$

A 58-year-old retired engineer presented with a 20 -year history of right wrist pain, swelling and decreased function. Examination revealed tenderness over the dorsal lunate, decreased wrist flexion-extension arc and decreased grip strength. $\mathrm{KD}$ is more common in men and rarely affects bilateral wrists. ${ }^{1}$ The symptoms of KD are insidious and easily mistaken for a minor wrist injury.

Early disease may appear normal on plain radiographs with pathological change only evident on MRI. ${ }^{1}$ Our patient's radiographs demonstrated a sclerotic fragmented lunate with loss of lunate height (figure 1) and CT imaging determined that the radiocarpal and intercarpal joints were relatively well preserved (figure 2).
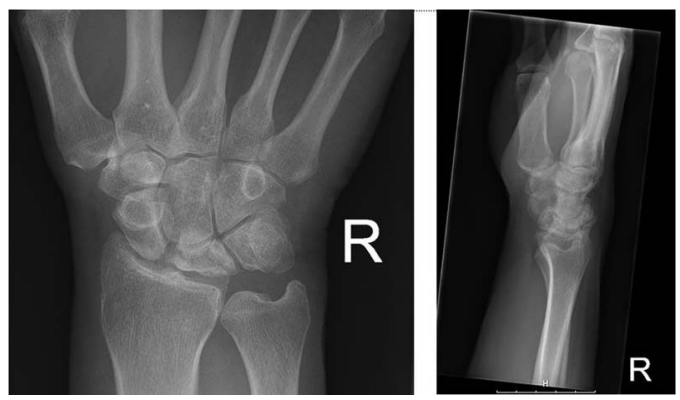

Figure 1 Preoperative radiographs of the right wrist (anteroposterior and lateral views).
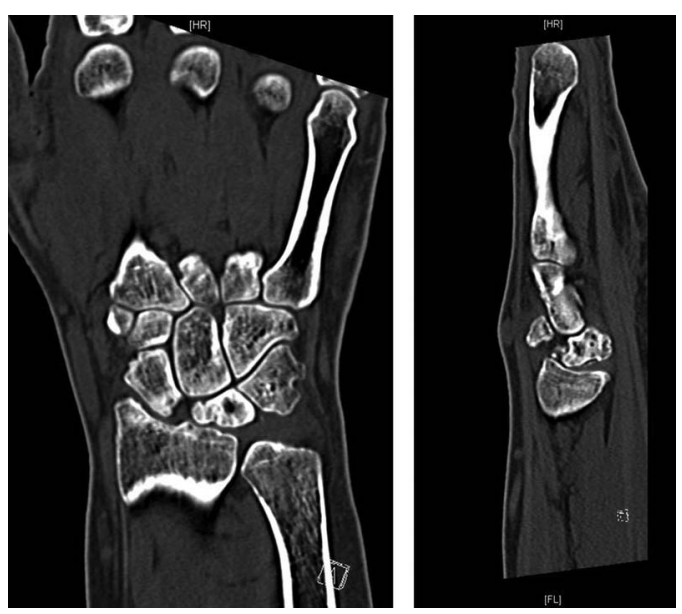

Figure 2 Preoperative CT images of the right wrist (coronal and sagittal planes).

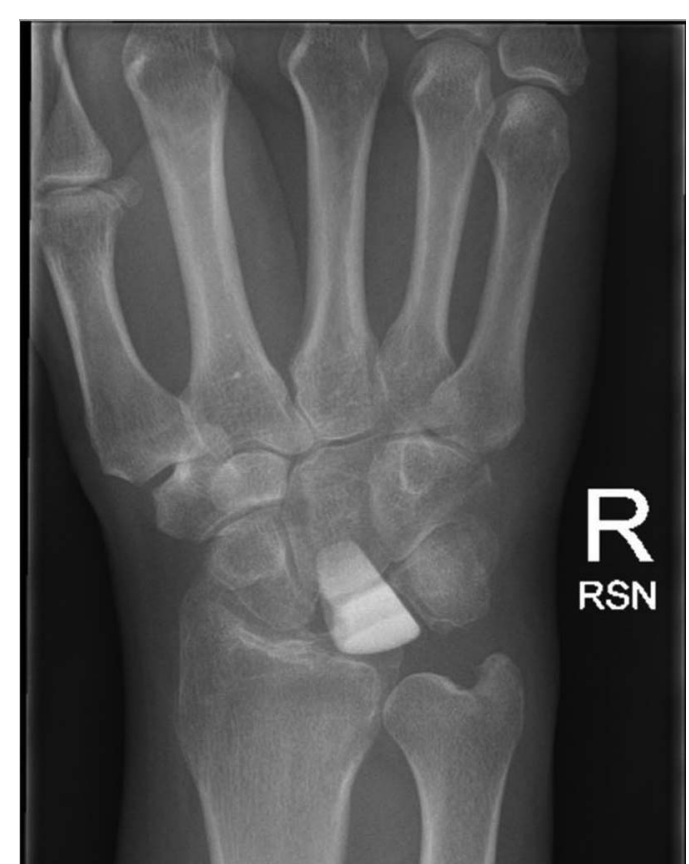

Figure 3 Postoperative anteroposterior radiograph of the right wrist.

Treatment aims to relieve pain, preserve motion and improve function. ${ }^{1}$ Treatment depends on the severity of disease and patient-specific factors, but there is no gold standard treatment. ${ }^{1}$

Our patient underwent excision of the necrotic lunate fragments and pyrocarbon lunate replacement (figure 3). This removes the degenerate lunate and offers good pain relief while maintaining the wrist's range of movement. Also, should this procedure fail, other surgical options are maintained. This is important as pyrocarbon lunate replacement is not yet supported by long-term follow-up studies and previous attempts to replace the lunate with ceramic, allograft or silicone materials have had mixed results. ${ }^{2}$

\section{Learning points}

- Kienböck's disease should be considered in patients presenting with insidious unilateral wrist pain, especially in middle-aged men with a pre-existing history of wrist trauma.

- Radiographic imaging can stage Kienböck's disease and guide treatment although plain radiographs may be normal in early disease. MRI is more sensitive.

- Kienböck's disease is of unknown aetiology but may result from a combination of vascular, anatomic and traumatic insults. 


\section{Images in...}

Contributors DJD produced the manuscript. REA supervised the production of the manuscript.

\section{Competing interests None.}

Patient consent Obtained.
Provenance and peer review Not commissioned; externally peer reviewed.

\section{REFERENCES}

1 Cross D, Matullo KS. Kienböck disease. Orthop Clin North Am 2014;45:141-52.

2 Viljakka T, Tallroth K, Vastamaki M. Long term outcome (22-36years) of silicone lunate arthroplasty. J Hand Surg Eur Vol 2013;39:405-15.

Copyright 2014 BMJ Publishing Group. All rights reserved. For permission to reuse any of this content visit http://group.bmi.com/group/rights-licensing/permissions.

BMJ Case Report Fellows may re-use this article for personal use and teaching without any further permission.

Become a Fellow of BMJ Case Reports today and you can:

- Submit as many cases as you like

- Enjoy fast sympathetic peer review and rapid publication of accepted articles

- Access all the published articles

- Re-use any of the published material for personal use and teaching without further permission

For information on Institutional Fellowships contact consortiasales@bmjgroup.com

Visit casereports.bmj.com for more articles like this and to become a Fellow 